Pia Salo, Outi Veivo \& Leena Salmi**

\title{
Building Pre-professional Identity during Translator Education - Experiences from the Multilingual Translation Workshop at the University of Turku
}

\begin{abstract}
Against the backdrop of the constantly changing professional environment, translator education needs to invest in the work readiness and employability of its graduates. This article explores translation students' emerging professional identity, referred to here as pre-professional identity (PPI) and its relevance for enhancing work readiness.. For this purpose, we have examined self-reflective essays written by translation students participating in a translation business simulation as part of their MA studies. The findings suggest that, in order to support students in building PPI, to facilitate the transition to the labour market, and to foster employability, it is useful to provide students with pedagogical approaches based on experiential learning combined with opportunities for critical self-reflection.
\end{abstract}

\section{Keywords}

pre-professional identity; translator training; experiential learning; employability; working life readiness; self-reflection

\section{Introduction}

This article explores the emerging professional identity of translation students. Working life values soft skills and competences that are transferable from one profession and career to another. Why, then, is the concept of professional identity - and the study of professional identity - still relevant and important, in expert work and in the field of professional translation in particular? Firstly, the insecure status of translation as a profession makes it a fruitful subject for such study (Sela-Sheffy 2016: 135-136; 2014: 50). This contrasts with the underlying potential of translators as cultural mediators, that has arisen in the current era of globalization and migration (Sela-Sheffy 2016: 135). A further argument for studying the professional identity of translators is that changes in working life are constant and accelerating. Technological developments and new forms of work have brought along a shift towards a boundaryless working life. Boundaries can be defined in terms of their flexibility (control over when and where work is performed) and permeability (the extent to which boundaries allow a person to be physically located in one domain while being psychologically in another role) (Field 2018). At the same time, it is necessary to recognize the realities of the self-employed professionals: they often work in networks with constantly changing structures and dynamics (Abdallah/Koskinen 2007). All this requires multiple professional identities as well as the constant renegotiation of acquired identities, highlighting the need for supporting identity work (Eteläpelto 2007). This renegotiation is not about passive accommodation to the changes in the surrounding world, but instead requires active processing of one's own professionalism in relation to the changes. To facilitate this work, it has been suggested that professional identity negotiation should be considered a key working-life skill (Hökkä 2015).

\begin{tabular}{lll}
\hline Pia Salo & Outi Veivo & Leena Salmi \\
School of Languages & School of Languages & School of Languages \\
and Translation Studies & and Translation Studies & and Translation Studies \\
University of Turku & University of Turku & University of Turku \\
E-mail: piasal@utu.fi & E-mail: outqvi@utu.fi & E-mail: leenie@utu.fi
\end{tabular}


In Finland, roughly a quarter (26\% in 2016) of translators, interpreters and other linguists work as entrepreneurs (Statistics Finland 2017). A survey commissioned by the Finnish Ministry of Economic Affairs and Employment in 2017 sheds light on self-employment in Finland (Koramo et al. 2017). With the emergence of new ways of working, the concept of self-employment is needed as an umbrella term signifying the form of work covering those who work in their own business with no employees or work entrepreneurially with no company form, excluding farmers. These groups include solo business owners, private traders ${ }^{1}$, freelancers and individual grant holders. The survey confirms that while the self-employed are generally fairly content with their form of work, the level of contentment tends to be heavily linked with the field of work. In fact, according to the survey, self-employed translators are among those who are very discontented with their form of work (Koramo et al. 2017: 63-64).

In a recent survey among those graduated from the translator programme at the University of Turku (Lahikainen 2019), 53\% of the respondents $(n=159)$ worked as employees and $33 \%$ were self-employed. It is worth noting that the proportion of the self-employed is considerably higher compared to graduates at the Universitat Autònoma de Barcelona (Galán-Mañas 2017). The survey was addressed to respondents who had graduated either during the years 1994-2003 or 2009-2016. The more recently graduated were more typically self-employed than those who had graduated earlier. The respondents considered that their studies had been weak in providing skills needed in working life, and strong in developing linguistic and translation skills.

In recent years, employability and work-readiness of translation students has been a recurrent topic in both academic and industry discussions. Competence models (PACTE 2000; Thelen 2006; Vandepitte 2009; EMT 2017), surveys focusing on the expectations of the translation industry (ELIA, EMT, EUATC, FIT Europe, GALA and LIND-Web 2019) or laying out the outline for the translation process (the ISO 17100 standard), are not adequate to fully address the complex needs of current or future working life. Moreover, taking into account the proportion of selfemployment as a form of work in the language industry in Finland, there is a need to incorporate entrepreneurial skills into translator education.

Drawing on the above-stated aspects, we argue that it is all the more important to support translation students in building their early-stage professional identities so as to prepare them for working life and to promote their employability. This article examines the pre-professional identity (PPI) of translation students. It also aims to raise awareness of the crucial role of PPI in the transition of graduates to the working life. There is a research gap in this area, as previous studies on translator identity focus on established professionals.

Consequently, in this article we look at the emerging professional identity of translation students. We are interested in what students say about their readiness for the working life and finding their own place professionally. In particular, we examine the components of PPI, and discuss possible implications for both graduate employability and translator training. For this purpose, we examine self-reflective essays produced by translation students.

\section{Pre-professional identity of translation students}

Identities are not something readily available at the professional identity supermarket - instead, they need to be built individually. Identity is formed in a continuing process of reflecting on fundamental questions, such as 'who am I', 'where do I belong' and 'what do I relate to'. In terms of professional identity, pivotal considerations include 'who am I as a professional', 'what do I want to become' and 'what values do I adhere to' (Hytti 2003; Hägg 2011). Professional identity encompasses an understanding one's professional goals and commitments as well as perceptions of meaningfulness of work and future orientations as professionals. It also involves planning one's future pathway as a professional and realizing one's preferred identity positions

1 Private trader is a term used by various instances in Finland, for example the Finnish Patent and Registration Office. Please consult https://www.prh.fi/en/kaupparekisteri/yrityksen_perustaminen/privatetrader.html. 
within work communities (Harteis/Goller 2014; Vähäsantanen et al. 2017). The above-mentioned considerations are all relevant in the formation of pre-professional identity.

In translation studies, identity research focuses on mid-career professionals, while the process of identity formation of emerging professionals has attracted little attention. Jackson (2016; 2017) has studied the emerging professional identity in higher education and calls the emerging, less mature version of professional identity of students pre-professional identity (PPI). She defines it as "an understanding of and connection with the skills, qualities, conduct, culture and ideology of a student's intended profession" (Jackson 2016: 926). The definition marks the conception that students are becoming, rather than being a professional (Scanlon 2011) and are what De Weerdt et al. (2006) describe as pre-accredited professionals. In Finland, the initial professional identity formation has been investigated in the context of teacher students during the pedagogical studies of teacher training and the first years in the profession. The findings underpin the importance of the initial identities and the storytelling process in teachers' professional identity formation (Ruohotie-Lyhty 2013).

Many of the components of PPI overlap with attributes connected to employability in higher education. Such components include the ability to reflect on experiences, an understanding of responsibilities involved, professional knowledge and expertise, self-directed learning, critical self-evaluation and reflective practice, career management as well as a sense of meaning (Jackson 2017: 837).

Although identity is subject to constant change and renegotiation (see Hytti 2003: 49), we suggest that the emerging professional identity, which the students acquire during studies, will affect their employability. The development of PPI has, however, not been studied to the same extent as other aspects of graduate employability (Jackson 2017: 834).

During the past two decades the sociological research approach has gained increasing attention within translation studies. As a result, sets of analytical concepts originating in the social sciences have been introduced into translation studies. Among the most well-established approaches acquired for examining the translation process and translatorship in social context are the conceptual frameworks of Pierre Bourdieu and Bruno Latour. Bordieu's sociology and his notion of habitus, in particular, has been utilized in various studies on the translator's identity (Simeoni 1998; Meylaerts 2010; Gouanvic 2014; Sela-Sheffy 2016). Simeoni (1998: 32) defines the habitus of a translator as "the elaborate result of a personalized social and cultural history". Vorderobermeier (2014: 15) sees a "real danger" in the recent trend of adopting the concept of habitus as an 'analytical tool' for research and pursuing an "application-centred approach with a tendency to neglect the fundamental commitment to a necessary interconnection between conceptual and methodological aspects". The concept of habitus and its suitability for the study of translatorship has also been criticized for disregarding the individual's motives and selfperception (Sela-Sheffy 2016: 44).

Identity can also be observed from the self-evaluation perspective. The ability to evaluate one's own performance relates to the concept of self-efficacy. Grounded in social cognitive theory, self-efficacy refers to believing in one's own capabilities of accomplishing a task or achieving a goal (Bandura 1997). It has become a fairly popular concept in both entrepreneurial research and practice (Gibb 2011: 11), because it "underpins the importance of instilling competency (know how) and capacity to act", and has for this reason been considered fit for investigating translator's agency (Gibb 2011: 11). In her extensive work on the self-efficacy beliefs of translation students, Haro-Soler (2019) found that a collaborative learning environment favoured vicarious learning and had a positive impact on the students' perception of their self-efficacy beliefs. Recent studies with interpretation students in Korea (Sang-Bin 2013) and translation students in Finland (Penttilä 2019) reinforce the complex nature of self-efficacy. Sang-Bin's (2013) findings are cautiously positive regarding the usefulness of a scale for Interpreting Self-Efficacy (ISE) in predicting interpreting performance. Penttilä (2019) found that self-reflection as an integral part of translator 
education helps students form a sense of self-awareness and gain an understanding of professional requirements in relation to their own capabilities.

Professional identity is not restricted to the individual level, but the formation of collective identity should also be considered. Collective identity is understood as forming a mutual understanding of "who we are as professionals" (Hägg 2011; Vähäsantanen et al. 2017). According to Wenger (1998), professional learning and identity construction are intertwined, taking place in communities of practice. Identity is renegotiated in relation to the participation in the community and experiences gained in it (Wenger 1998).

We propose embracing the concept of professional identity to facilitate the transition to the labour market and to foster employability. Thus, the aim of this study is to explore the formation of the pre-professional identity of translation students. In this context, PPI is understood as the emerging professional identity that develops as a result of the understanding of "the skills, qualities, conduct, culture and ideology of a student's intended profession" (Jackson 2016: 926). The definition marks the conception that students are becoming, rather than being a professional (Scanlon 2011) and are what De Weerdt et al. (2006) describe as pre-accredited professionals.

\section{Multilingual Translation Workshop (MTW) as a learning environment}

In this section, we describe how working life simulation is utilized as a learning environment in translator education at the University of Turku. Our Translation Studies Degree Programme belongs to two international networks: the European Master's in Translation (EMT), a network of universities offering master's level training for translators, as well at the International Network of Simulated Translation Bureaux (INSTB), a partnership of universities that use simulation of work in a translation agency in their curriculum "to increase graduate employability by offering students practical, market-oriented experience during their studies" (INSTB 2019). At the University of Turku, the simulation takes place in the Translation Workshop (MTW) courses.

Similar concepts utilizing experiential learning and translation company simulation include the Maastricht Skills lab (Thelen 2006) and the Rennes Tradutech (Gouadec 2005), and corresponding initiatives have also been offered in an online environment (Olvera-Lobo 2005; 2009).

\subsection{Students as learners in the MTW}

The MTW is a compulsory part of the Multilingual Translation Studies Degree Programme at the University of Turku, Finland (Konttinen et al. 2017). When entering the MTW, the students have completed one term in the Master's Degree Programme studying preparatory courses, such as basics of professional translation, translation technology and professions in the translation field. The MTW is a year-long course composed of two modules (10 ECTS each) based on a working life simulation. The students are divided in multilingual groups of 4 to 7 students and each group sets up their own virtual, simulated translation company. In this pedagogical approach based on experiential learning (see e.g. Lewis/Williams 1994), students go through the different phases of starting a new business: they choose a name for their company, write a business plan including pricing principles, design a company website, and get their translation tools ready in order to take in assignments from customers. The students are given descriptions of different roles involved in the translation workflow based on the ISO standard for translation service management (ISO 17100: 2015), based on which they assign a role or multiple roles for each member in the student company. In the first module of the MTW, the students change roles after each assignment (7 assignments during the 15-week term). In the second module switching roles is optional. In other words, they can specialize in the role that they think fits them best and remain in that role for the whole term. During the MTW, teachers act as customers and contact the companies via email requesting translation services. While most of the assignments are simulated (fictitious) and prepared by the teachers, some of the assignments are received from authentic (real) customers. The assigned project manager communicates with the customer, handling inquiries and negotiating 
the pricing and the schedule. The project manager plans the translation workflow and divides the work within the company.

After each assignment, the performance of the student companies is evaluated based on the service provided (communication with the customer) and for the final products delivered (translated documents, term bases, translation memories). In addition, the students reflect on their individual development and experiences in the given role after each assignment. These selfreflective essays are used in the present study to analyze the students' pre-professional identities.

The MTW is a translation market simulation that has multiple learning objectives. Having completed the MTW modules, the students are expected to be experts in their given language pair but also to know what is involved in setting up and managing a translation organization. They should be familiar with different roles and tasks in a translation organization after their experience as project managers, terminologists, translators, revisors, proofreaders and as IT support in their company. Additionally, they are expected to understand the translation workflow and to have enhanced their translation and information-seeking skills. They are also expected to be able to use translation technology and to organize and administer the scheduling, resourcing, quality assurance and pricing of translation projects using project management tools. The aims of the MTW pedagogy also include improved team and communication skills, and the ability to evaluate and develop the quality, efficiency and profitability of a translation company. The development of the different competences in the MTW was evaluated by Konttinen et al. (2017), and the results indicated the efficiency of the MTW pedagogy in developing students' project management, financial administration, marketing and IT skills, in particular.

\subsection{The MTW pedagogy}

In this section, we describe the approaches around which the MTW pedagogy is built and explain how it relates to employability, working life readiness, and more broadly, entrepreneurial competences. To achieve the learning objectives described above, the MTW provides a learning environment that draws on entrepreneurial pedagogy, relying on approaches such as learning by doing (Dewey 1938), ownership of learning, learning by trial and error (Gibb 2011: 11), simulation (Faria 2001), and authentic learning (Braund \& Reiss 2007).

In Wenger's terms (1998), the MTW can be seen as a community of practice, in which students construct their pre-professional identities. It could also be considered a form of Work-Integrated Learning (WIL), which is "the interweaving of practical work experience with classroom learning" (Jackson 2017: 835). In contrast to placement WIL, where students spend a period of time in the workplace as part of their studies, simulation as a learning environment falls into the category of non-placement WIL, allowing placement or practicum type learning experience in a classroom or virtual setting (Jackson 2017: 835).

Jones/Iredale (2010) clearly differentiate between two concepts: entrepreneurship education and enterprise education. They claim that while the former focuses on the process of starting, growing and managing a business, the latter aims at developing the students' personal skills and abilities that they can make use of in different contexts. From a pedagogical perspective, entrepreneurship education tends to rely on didactic approaches, while enterprise education utilizes more innovative approaches, allowing greater student ownership of the learning process (Jones/Iredale 2010: 10-14). The MTW pedagogy combines elements of both approaches.

Entrepreneurial skills are also present in the EMT Competence Framework. The EMT has updated its framework for translator and translation competence in 2017, taking into account the changes that have taken place in the language industry since the publishing of the previous framework in 2009. The 'Service provision' dimension of the updated framework refers to entrepreneurial skills, although not explicitly. While several of the more practical sub-competences in this dimension can be seen as entrepreneurial competences, there are two sub-competences, in particular, that refer to a wider understanding of the language industry, and that we suggest also 
fall into the definition of entrepreneurial mindset: "[m]onitor and take account of new societal and language industry demands, new market requirements and emerging job roles" and "[a]nalyse and critically review language services and policies and suggest improvement strategies" (EMT 2017). The MTW has a strong focus in developing such skills by relying on a combination of the pedagogical approaches described above.

Having students reflect "upon their own values, beliefs, feelings and teaching practices and experiences helps shape their professional identity" (Izadinia 2013: 699). Jackson (2017: 839) reminds that a lack of evaluation and reflection in connection with practical experience may lead to students simply imitating existing - perhaps poor - practices and not taking advantage of valuable opportunities to develop crucial skills, such as problem solving, critical reflection and innovative thinking.

One of the strongest assets the MTW can offer students, given the fact that it runs for two whole semesters, is that it allows them an extended period of time to reflect on what they have learned and how they feel about their experiences. Most importantly, the students have a chance to integrate these new experiences to the collection of their prior understanding of working life as well as the academic knowledge from previous study courses.

\section{Material and method}

To explore how translation students construct their pre-professional identities, data was collected during the first module of the Multilingual Translation Workshop in the Spring term 2018. After each simulated assignment $(n=7)$ completed during the workshop, the students $(n=18)$ were instructed to fill in a self-reflective questionnaire with six open-ended questions. They were asked to answer with 50-100 words to each question. While most of the tasks in the MTW are performed as a team, this assignment was designed as an individual reflection on both teamwork and individual performance - and most importantly, finding one's place as a professional. The students were asked to reflect on their experiences during the MTW.

As a result, a data set of 71,672 words was produced (including the questions given as guidance for the self-reflections), of which answers to two questions were selected for examination in this study. For the purposes of this study, we examined the segments of the reflective essays focusing on 1) how the students found working in the particular role, and 2) could they picture themselves working in this particular role in the working life, and why.

Students were not explicitly asked to consider the development of their professional identity, nor were they given a definition of PPI. Instead, the open-ended questions allowed them to reflect on their experience in the context relevant for this study. This improved validity, as self-reported levels of development tend to be overestimated (Nadelson et al. 2015: 706).

Three components of PPI were identified as a base for analysis. They were guided by the conceptual framing of PPI presented in section 2 and were considered suitable for the context and the objectives of the study. The following components were defined for examining the development of PPI:

1. What are my responsibilities and what is expected from me as a professional

2. Who am I as a future professional

3. Where do I fit in the professional community

An Interpretative Phenomenological Analysis was conducted to capture and understand the experience of the participants. The overall process can be described as "a rigorous iterative process of being disciplined by the data, looking for empirical evidence of patterns, and seeking logical arguments in how patterns relate" (Adams 2011: 592).

In the first phase (descriptive), each piece of data (i.e. each of the individual segments chosen as explained above) (written in Finnish) was examined independently in order to identify 
emerging themes. This was done by summarizing (in English) the main points of each segment in a descriptive summary. In the second phase (interpretative) an independent interpretation was formed first for each segment of the self-reflections under examination, after which patterns were identified across the individual cases. By examining such patterns, it was possible to illuminate similarities and differences between cases. It is worth noting that participants can have a similar experience of components of the phenomenon of interest but form very different interpretations (Miller 2018:243). In the context of the MTW this means, for example, that a translation assignment with a tight deadline could be a motivator for one student, but a trigger for unnecessary stress for another, thus hindering effective work. The phases of the analysis are summarized below.

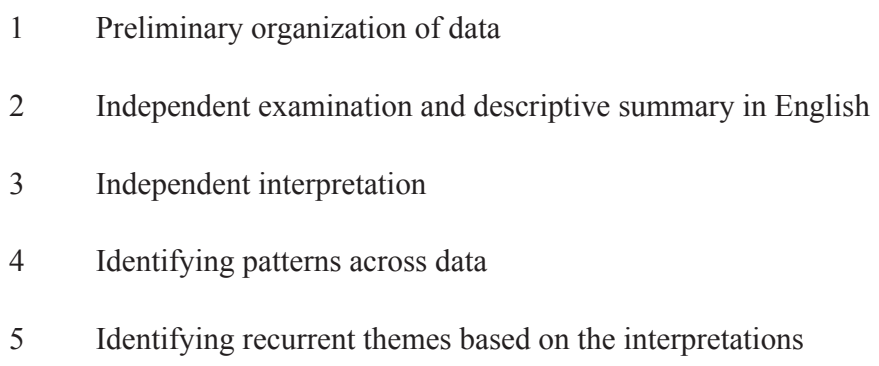

While we acknowledge that the students practice working in different roles during the simulation, we have explicitly avoided analyzing the data merely in the context of the specific role(s) that the student has discussed in that specific essay. This allowed a more data-driven analysis and enabled us to understand the construction of the pre-professional identity as a process and build a framework of the key factors involved in the process.

\section{Building PPI in the MTW}

The aspects of PPI defined in the previous section were scrutinized in the analysis. Recurrent themes were identified for each aspect. The findings are summarized in Table 1. below. 


\begin{tabular}{ll}
\hline Aspect of PPI & Theme \\
\hline What are my responsibilities and what is & Reflecting on responsibility, accountability and leadership \\
expected of me as a professional? & Exposure to new tasks, working methods and technology \\
Who am I as a future professional? & $\begin{array}{l}\text { Exposure to challenging and fast-paced environment } \\
\text { experience }\end{array}$ \\
& Finding meaning in work \\
& Identifying areas for development \\
& Reflecting on feelings arising from the experience \\
& Building confidence by finishing tasks successfully and \\
& receiving constructing and encouraging feedback \\
& Gaining knowledge of the industry and professional roles \\
& Identifying personal strengths and weaknesses \\
& Identifying possible career paths \\
& Understanding of organizational and hierarchical structure \\
& Realizing the importance of belonging to a professional \\
& community \\
Understanding the importance of teamwork and \\
community?
\end{tabular}

Table 1. Building PPI in the MTW

The table presents an overview of the themes identified in the examination of the data. What follows in the next subsections, is a discussion of the findings with data excerpts for illustration, within each of the three aspects.

\subsection{What are my responsibilities and what is expected from me as a professional}

Being exposed to a simulation with a feel of authenticity is reflected in that the students report a sense of responsibility. It is evident in the data that these frequently trigger feelings of overwhelmingness and stress but also feelings of meaningfulness. In the data, vague expectations (either due to unclear instructions provided by the fictitious client or unclear areas of responsibility) are also mentioned as a source of stress and nervousness. Other causes of stress are working on an assignment from a real customer, the pace of work, and translating into a second language.

Most students were new to responsibilities related to managing, organizing and leading. After experimenting in such activities most of them express unwillingness to take on work involving managerial responsibilities, unless they get a chance to have more practice. One of the students mentions he/she doesn't see himself/herself as the leader type, "at least not yet, and would rather work in the ranks of employees"'. The findings are in line with the results of Kuznik and Verd (2010) in that managerial tasks were perceived as complex by students. In addition, our findings highlight the weight of the accountability reported frequently by students and the stress triggered by it.

Some students see the opportunity to gradually grow into new types of expectations and responsibilities, For example, in the following excerpts students describe their overall experience as positive, and keep their future career options open even after an intimidating initial experience:

2 The quoted excerpts taken from the students' self-reflective essays were originally written in Finnish and translated into English by the authors of this article. 
I enjoy teamwork but I would not want to work as a team leader. I think this is something that could change over time with more experience.

The burden of responsibility made me nervous beforehand, but in the end I could say that I enjoyed the experience. I could see myself doing this again, despite the fact that I normally don't consider myself the leader type.

\subsection{Who am I as a future professional}

The students demonstrate an ability to reflect on possible career options in relation to the experience at the MTW, connecting it to prior experiences and conceptions of what they are as a future professional. This process shown in the self-reflections can be identified as starting professional identity negotiation.

In terms of reflecting on the MTW experience in the context of one's professional aspirations, the experience triggers differing outcomes: it either reinforces previously formed conceptions or opens up new professional options. After reflecting on the experience, some students conclude that they do not see themselves working in particular tasks:

\footnotetext{
Gaining more experience would probably release feelings of stress, but I suspect working in project management in a real company would not be the most suitable position as I tend to get easily stressed. Being responsible for the whole company would be too much.
}

The experience in the MTW is an opportunity to identify one's own strengths and weaknesses and how to utilize them in a professional context. Exposure to new experiences in the MTW has also awakened students to new possibilities and the realization of areas of development. The most common areas of development are related to general managerial and organizational tasks. In addition, there are cases where a student has had a self-perception where he/she feels that certain type of work would not suit his or her personality, but once they had the chance to experiment with such tasks in the MTW, the experience ended up being better than anticipated. Here, a student reflects on such an experience:

\footnotetext{
I could not see myself working in project managerial tasks because it involves a great deal of responsibility and requires advanced management and leadership skills. However, thinking of the future, I don't want to rule out the possibility completely: after having experimented in these tasks and finding that I succeeded to some extent, I feel in time I might develop into somewhat of a leader.
}

It is no surprise that the students felt most comfortable with translation tasks. It is evident from the data that this forms the core of their pre-professional identity. Translating into a second language and working with new types of assignments or texts involving unfamiliar terminology or translation tasks requiring unfamiliar technology brings forth some uncertainty, but the students were confident that these new skills relating to the core of translatorship were something that they could acquire. Students also reported finding some of the text types or fields unmotivating, but realized it is rarely possible to only work on the types of assignments they find interesting and rewarding.

In addition to being introduced to new roles and tasks, equally important in terms on building PPI, is that the students were also able to develop a deeper and more complex understanding of translating, in which they were fairly confident in to start with:
I feel that I picked up different layers in the text more clearly. [The experience also] made it all the more clear that translation certainly isn't just replacing words with those in another language. I would gladly work in this type of position, in which I gain confidence and feel that I am skilled.

Although the role of the translator was the most familiar to the students, the MTW presented it in a new context, a more authentic environment simulating authentic working life. Among new aspects to translating, the students mention coworking with other translators and other language specialists (proofreader, reviewer, terminologist) as well as other specialists in the team, being introduced to new technology, working according to client instructions. There were, however, 
cases, where translating was described as a 'routine-like', 'effortless' and 'familiar' task, and a self-evident choice for number one career path:

Of course [I could see myself as a professional translator]. Becoming a translator is what we are aiming for here.

It is encouraging that after the experience, none of the students express an unwillingness to pursue work as a translator. Many of those, who, after the MTW, see a wider professional spectrum open up as possibilities, specify that they would like these additional tasks to form a part of their professional role. Proofreading, reviewing, terminology work and desktop publishing are seen as an addition bringing versatility to the core task, and providing useful addition to professional competence.

It is worth noting that only one of the students explicitly referred to him or herself as an expert in translation, but emerging expertise was evident in the data. One of the students, in particular, stated that "It feels great to be so good at something, that I am the one being asked for consultation", referring implicitly to expertise.

Gaining confidence during the MTW, which is key in building PPI, was a recurrent theme. Most notably, the students felt confident when they, in the course of the MTW, became aware of their existing competences: "During this assignment I became aware of my competences, which gave me self-confidence." However, there is a lack of confidence seen in the tendency to look for a soft landing to the professional career, where one would move up in the hierarchy:

I could see myself working as a project manager at some point. At the moment, however, I feel I am only just learning the basics of project management, and don't know how I would do in project management in the working life in terms of being convincing or stress-free.

The findings related to gaining confidence are strongly supported in Haro-Soler's study (2017). According to Haro-Soler (2017: 145-146), one of the agents having a positive influence on translation students' professional confidence was a participatory teaching approach adopted by the teachers. This meant that the students were encouraged to reflect on the decisions taken and errors made, as well as identify problems and develop problem-solving strategies.

Two of the students clearly state that they aspire to a career as a self-employed individual or entrepreneur, and the experience at the MTW has reinforced this aspiration. Several students are open to this option, among other possibilities, but state that they need more knowledge and that they have concerns regarding their inadequate understanding of business economics, pricing and profitability: "I would also need to know about profitable pricing and to follow the market constantly".

\subsection{Where do I fit in the professional community}

This dimension includes areas of PPI that relate to the formation of the collective identity. During the MTW, the students should all get to try out the different roles and gain a glimpse of what each role involves and how it fits into the provision of translation services as a whole. In many of the assignments some students were assigned several roles in the team, and the assignments required a varying level of work. For these reasons, the experiences were not equally comprehensive. This is reflected in the students' essays, when they report not being able to reflect on certain elements due to their limited experience.

The very concept of the MTW fosters the formation of collective identity, as students form teams and work in them from the beginning. While teamwork caused confusion, in particular in the beginning, with no established ways of working, teamwork was frequently reported as helpful. The teams report working together both physically and virtually. In the data, students reported sharing responsibilities and having a sense of belonging, which are illustrated in the following quotations: 
I didn't have much to do at this point, but I tried to do my best to assist with anything I could. [...] I wanted to be present to show that I am available for help, if needed.

We spent an hour physically in the same space working on the termbase, otherwise we collaborated virtually, simultaneously. Collaboration really paid off.

Team-building was not a smooth process in all teams but required extra effort: one of the students specifically describes noticing that the team had difficulties in getting started, choosing to step up and taking initiative in order to boost team spirit. This shows ownership of learning but can also be seen as a key asset in terms of employability. The same student says, however, that although he or she "enjoys being in control, on the flipside, it can still be burdensome".

Based on the data, the simulation works well in terms of introducing teamwork and gaining knowledge regarding the different roles and stages involved in providing professional translation services. However, the data reveals that while the students develop a conception of organizational and hierarchical structure, they tend to see it as fairly fixed and stable, in contrast to the flexible and vulnerable structures present in the language industry today.

Several students have a conception of the project manager as having responsibility for the whole business. In the context of the MTW, this is understandable as, due to the MTW concept with specified roles, the student companies have no assigned Managing Director, and the concept operates around companies with salaried employees. The assigned project manager takes care of general management in addition to coordinating assignments. The data shows a tendency to generalize the conception of organizational structure and hierarchy formed in the MTW, based on the way the student companies are organized. This is, however, not desirable, as in real life the organizational structure is not this straight-forward, but the organizational and hierarchical arrangements depend on the company type chosen. Having a basic knowledge of different types of organizations is desirable. Moreover, considering that a significant portion of translators in Finland are self-employed, an understanding of this form of work would be essential when entering the working life.

As a way to cope with a new, exciting, even intimidating environment, the students tend to rely on shared responsibility. Particularly in the very first assignment, when there were no established ways of working, students had to find ways to cope with unclarity, and found a solution in shared responsibility. In the following example the student assigned for project managerial tasks in the very first assignment reflects on the experience:

\footnotetext{
It was really challenging and hard to take care of project management in the first assignment with no previous role model. At times I felt completely adrift. I didn't even try to be on top of the project as a whole. Instead we shared responsibility and solved problems on the way as we encountered them. I feel that my organizational skills are not as strong as needed.
}

Following from the conception of the project manager's role and the responsibility associated with it, when reflecting on possible career pathways, project managerial tasks were not the preferred choice among students:

Project managerial role is not appealing to me because of the level of responsibility associated with it. After all, a Project Manager is responsible for keeping clients happy and has a major responsibility financially. PM needs to make sure that the company generates profit for its owners and that the employees' pace and quality of work as well as the salaries are at the required level.

\section{Discussion and conclusion}

The aims of this study were to bring attention to the formation of pre-professional identity as an integral part of employability of translation students and to explore more closely the role of the MTW in building PPI. As a result, a conceptual framework of PPI was developed, illustrating how the defined components of PPI are built in the MTW. 
The findings show that overall, the MTW helps students to establish an understanding of how the translation business works and which parties are involved in a translation project (see Konttinen et al. 2019). This is valuable in terms of making informed career choices. The findings reinforce the argument that practice and participation are crucial in building PPI. In terms of working life readiness, the MTW also made students realize that where they most need to gain experience and knowledge are tasks related to running a business and putting a price tag on one's own work performance, in particular. When graduates gain a sufficient knowledge about the realities of working in the language industry, the transition into the profession is more likely to be smoother.

The students felt that during the simulation they gained insight into the possibilities, requirements and expectations of their profession. Based on previous knowledge and experience, the students have a preconception of what a translator does. Against this background, they reflect on their own strengths and weaknesses as well as interests and professional goals, to define what type of work they themselves want to focus on. Based on the results, a working life simulation, such as the MTW, can reinforce the preconception, help students to identify their strengths and weaknesses, and to bring up new possibilities to their career radar. More importantly, it can be concluded that the MTW as an experiential learning environment, along with the opportunity for self-reflection, has a crucial role in starting a process, in which the students need to ask themselves who they are and what they want professionally, and what steps do they need to take to advance to the desired direction - all essential building blocks of PPI.

As for the role of translator education in forming a pre-professional identity, the findings of this study support the views of Hunter et al. (2007) in that students should be provided with "workinglife experiences to reflect on as well as support by educators who understand their mentoring role". They also support the views expressed by the graduates from earlier years that the curriculum should contain more elements that support the transition to working life (Lahikainen 2019).

The fluctuating nature of modern working life makes professional goal-setting difficult. It is hard to predict what the language industry and professions will look like in ten years: looking back ten years, the changes have been dramatic. This yields challenges for both translation students and educators. In this environment, constant self-reflection and self-assessment are inevitable for professional growth. A possible tool for supporting the formation of PPI before graduation is to encourage self-reflection during translator training. The findings of this study can be of use in developing the MTW or other learning environments suited for this purpose.

One of the main challenges for any future professional in an expertise-based profession is that the demands of the working life and the prerequisites for building a professional identity are in conflict. The working life seems to put emphasis on transferable skills and the ability to quickly adapt to changes in environment, technology and forms of employment. Expertise, on the other hand, is something that is built over time and is traditionally based on specialization.

As with any self-reflective material, there are limitations deriving from the character of the material. The students may, for example, try to present themselves in a favourable manner. While presentations of identities can be identified based on self-reflections, factors such as the selfefficacy of students are involved. Further study is needed to understand self-efficacy of translation students more deeply. Furthermore, interpretation of data brings along limitations not be fully aligned with what the students intended to communicate.

The aim of this study was to capture the emerging professional identity. No sequential development was examined, given that the students face a new learning environment and experiment with several new roles during the 15-week MTW module. More longitudinal research is needed to explore the development of PPI, with a focus on newly graduated translation professionals over the induction phase, namely the first years in the profession. 


\section{References}

Abdallah, Kristiina/Koskinen, Kaisa 2007: Managing Trust: Translating and the Network Economy. In Meta 52 (4), 673-687.

Adams, Robin S. 2011: Being a Professional: Three Lenses into Design Thinking, Acting, and Being. In Design Studies 32 (6), 588-607.

Bandura, Albert 1997: Self-efficacy: The exercise of control. New York: W. H. Freeman.

Braund, Martin/Reiss, Michael 2006: Towards a More Authentic Science Curriculum: The contribution of out-ofschool learning. In International Journal of Science Education, 28 (12), 1373-1388.

De Weerdt, S./Bouwen, R./Corthouts, F./Martens, H. 2006: Identity transformation as an intercontextual process. In Industry \& Higher Education, 2 (5), 317-326

Dewey, John 1938: Experience \& Education. Reprint from 1963 by Collier Books, by arrangement with Kappa Delta Pi: New York.

Eteläpelto, Anneli 2007: Identiteetti ja työ rakenteiden ja toimijuuden ristiaallokossa. In Eteläpelto, A./Collin, K./Saarinen, J. (eds.) Työ, identiteetti ja oppiminen, Helsinki: WSOY, 90-142.

Faria, A. 2001: The Changing Nature of Business Simulation/ Gaming Research: A Brief History. In Simulation Gaming 32 (1), 97-110.

Field, J. C. 2018: Contemporary Knowledge Workers and the Boundaryless Work-Life Interface: Implications for the Human Resource Management of the Knowledge Workforce. In Frontiers in Psychology 9, 2414.

Galán-Mañas, A. 2017: Programa para la mejora de la empleabilidad de los egresados en Traducción e Interpretación. Un estudio de caso. In Conexão Letras, 12 (17), 153-171.

Gibb, A. 2011: Concepts into Practice. Meeting the Challenge of Development of Entrepreneurship Educators around an Innovative Paradigm. The Case of the International Entrepreneurship Educators' Programme (IEEP). In International Journal of Entrepreneurial Behaviour and Research 17 (2), 146-165.

Gouadec, Daniel 2005: Pédagogie par projets : le modèle rennais. In Gouadec, Daniel (ed.), Actes du Colloque international Traduction - localisation: technologies et formation, Rennes, 2004. Paris: La maison du dictionnaire, 33-108.

Gouanvic, Jean-Marc 2014: Is Habitus as Conceived by Pierre Bourdieu Soluble in Translation Studies? In Vorderobemeier, Giesella M. (ed.), Remapping Habitus in Translation Studies. Amsterdam: Editions Rodopi, $29-42$.

Hägg, Outi 2011: Yrittäjyysvalmennus ja yrittäjäidentiteetti. Academic dissertation. Tampere: Tampere University Press.

Haro-Soler, María del Mar 2017: Self-confidence and its role in translator training: The students' perspective. In Lacruz, Isabel/Jääskeläinen, Riitta, (eds.), Innovation and Expansion in Translation Process Research. Amsterdam: John Benjamins, 131-160.

Haro-Soler, María del Mar. 2019: Vicarious learning in the translation classroom: how can it influence students' selfefficacy beliefs? In English Studies at NBU 5 (1), 92-113.

Harteis, C./Goller, M. 2014: New skills for new jobs: work agency as a necessary condition for successful lifelong learning. In Billett S./Halttunen T./Koivisto M. (eds.), Promoting, assessing, recognizing and certifying lifelong learning: international perspectives and practices, Dordrecht: Springer, 37-56.

Hökkä, Päivi 2015: Ammatillisen identiteetin neuvottelu työelämätaidoksi. In Osviitta 4, 4-7.

Hunter, A./Laursen, S/Seymour, E. 2007: Becoming a scientist: The role of undergraduate research in students' cognitive, personal, and professional development. In Science Education, 91 (1), 36-74.

Hytti, Ulla 2003: Stories of Entrepreneurs: Narrative construction of identities. Academic dissertation. Turku School of Economics and Business Administration, Small Business Institute.

INSTB 2019: Welcome to INSTB: [online] http://www.instb.eu/ (accessed 17 June 2019)

ISO (International Organization for Standardization) 2015: ISO 17100: Translation Services - Requirements for Translation Services. Geneva: ISO.

Izadinia, M. 2013: A review of research on student teachers' professional identity. In British Educational Research Journal 39 (4), 694-713.

Jackson, Denise 2016: Re-Conceptualising Graduate Employability: The Importance of Pre-Professional Identity. In Higher Education Research and Development 35 (5), 925-939.

Jackson, Denise 2017: Developing Pre-Professional Identity in Undergraduates through Work-Integrated Learning. In Higher Education: The International Journal of Higher Education Research 74 (5), 833-853.

Jones, Brian/Iredale, Norma 2010: Enterprise Education as Pedagogy. In Education \& Training 52 (1), 7-19. 
Konttinen, Kalle/Veivo, Outi/ Holopainen, Tiina/Salmi, Leena 2017: Multilingual Translation Workshop - Developing professionals in a simulated translation market. In MikaEL - Electronic Journal of the KäTu Symposium on Translation and Interpreting Studies 10, 150-164.

Konttinen, Kalle/Veivo, Outi/Salo, Pia 2019: Translation students' conceptions of translation workflow in a simulated translation company environment. In The Interpreter and Translator Trainer. 1-16.

Koramo, Marika/Keinänen, Janika/Oosi, Olli/Wennberg, Mikko. 2017: Itsensätyöllistäminen ja jakamistalous työelämän murroksessa. [online] Ministry of Economic Affairs and Employment. http://julkaisut.valtioneuvosto.fi/ handle/10024/79272 (accessed 27 May 2019).

Kuznik, Anna/Verd, Joan Miquel 2010: Investigating Real Work Situations in Translation Agencies. Work Content and Its Components. In Hermes - Journal of Language and Communication in Business 44, 25-43.

Lahikainen, Eveliina 2019: Turun yliopiston kääntäjänkoulutuksesta vuosina 1994-2003 ja 2009-2016 valmistuneiden työhönsijoittuminen. Master's Thesis, University of Turku, Multilingual Translation Studies Degree Programme. [online]. https://www.utupub.fi/handle/10024/147970 (accessed 7 February 2020).

Lewis, L. H./Williams, C. J. 1994: Experiential learning: Past and present. In New Directions for Adult and Continuing Education 1994 (62), 5-16.

Miller, R. M. 2018: Interpretative Phenomenological Analysis: A Contemporary Qualitative Approach. In Counselor Education and Supervision 57 (4), 240-254.

Nadelson, L./McGuire, S./Davis, K./Farid, A./Hardy, K./Hsu, Y./Wang, S. 2015: Am I a STEM professional? Documenting STEM student professional identity development. In Studies in Higher Education 42 (4), 701-720.

Olvera-Lobo, M.D./Castro-Prieto, M.R./Quero-Gervilla, E./Muñoz-Martín, R./Muñoz-Raya, E./Murillo-Melero, M./ Robinson, B./Senso-Ruiz, J.A./Vargas-Quesada, B./Domínguez-López, C. 2005: Translator training and modern market demands. In Perspectives: Studies in Translatology 13 (2), 132-142.

Olvera-Lobo, M.D./Robinson, B./Senso, J.A./Muñoz-Martín, R./Muñoz-Raya, E./Murillo-Melero, M./Quero-Gervilla, E./Castro-Prieto, M.R./Conde-Ruano, T. 2009: Teleworking and collaborative work environments in translation training. In Babel 55 (2), 165-180.

Penttilä, Esa 2019: Jonkin verran käännösalan asiantuntijuutta Valmistuvien kääntäjäopiskelijoiden näkemyksiä kyvyistään minäpystyvyyden näkökulmasta. In MikaEL - Electronic Journal of the KäTu Symposium on Translation and Interpreting Studies 11, 90-103.

Ruohotie-Lyhty, M. 2013: Struggling for a professional identity: Two newly qualified language teachers' identity narratives during the first years at work. In Teaching and Teacher Education 30, 120-129.

Sang-Bin, Lee 2014: An Interpreting Self-Efficacy (ISE) scale for undergraduate students majoring in consecutive interpreting: construction and preliminary validation. In The Interpreter and Translator Trainer, 8 (2), 183-203.

Scanlon, L. 2011: Becoming a professional: an interdisciplinary analysis of professional learning. London; New York: Springer.

Sela-Sheffy, Rakefe. 2014: Translators' Identity Work: Introducing Micro-Sociological Theory of Identity to the Discussion of Translators' Habitus. In Vorderobemeier, Giesella M. (ed.), Remapping Habitus in Translation Studies. Amsterdam: Editions Rodopi, 43-55.

Sela-Sheffy, Rakefet 2016: Professional Identity and Status. In Angelelli, Claudia V./James Baer, Brian (eds.), Researching Translation and Interpreting. Milton Park \& New York: Routledge, 131-145.

Simeoni, Daniel 1998: The Pivotal Status of the Translator's Habitus. In Target 10 (1), 1-39.

Statistics Finland 2017: Employment in cultural industries and occupations weakened from the year before. [online] http://tilastokeskus.fi/til/klt/2016/01/klt_2016_01_2017-10-13_tie_001_en.html?ad=notify (accessed 27 May 2019).

Thelen, M. 2006: Going European: A Plea for Building a Network of Simulated Translation Bureaus. In Forstner, M./ Lee-Jahnke, H. (eds.), CIUTI-Forum Paris 2005: Regards sur les aspects culturels de la communication. Frankfurt am Main: Peter Lang, 219-236.

Vähäsantanen, Katja/Hökkä, Päivi/Paloniemi, Susanna/Herranen, Sanna/Eteläpelto, Anneli 2017: Professional learning and agency in an identity coaching programme. In Professional Development in Education 43 (4), 514-536.

Vorderobermeier, Gisella M. 2014: Introduction: (Translatorial) Habitus - A Concept that Upsets (in Translation Studies)? In Vorderobermeier, Gisella M. (ed.), Remapping Habitus in Translation Studies. Leiden: BRILL, 9-26.

Wenger, E. 1998: Communities of Practice: Learning, meaning and identity. Cambridge: Cambridge University Press. 